\title{
Open Patellar Fracture in a 2-Year-Old Child: A Rare Case Report
}

\author{
K. R. Gowtham, M. R. Nambiar, V. S. Vanishri \\ Sanjeevani Institute of Medical Science (SIMS), Kanhangad, India \\ Email: drgowthamkr1984@gmail.com,drmrnambiar@gmail.com
}

How to cite this paper: Gowtham, K.R., Nambiar, M.R. and Vanishri, V.S. (2016) Open Patellar Fracture in a 2-Year-Old Child: A Rare Case Report. Open Journal of Orthopedics, 6, 311-314.

http://dx.doi.org/10.4236/ojo.2016.610040

Received: July 1, 2016

Accepted: October 8, 2016

Published: October 11, 2016

Copyright $\odot 2016$ by authors and Scientific Research Publishing Inc. This work is licensed under the Creative Commons Attribution International License (CC BY 4.0).

http://creativecommons.org/licenses/by/4.0/

\begin{abstract}
We present this unusual fracture in order to stress the importance of being aware of the existence of open fractures of patella in 2-year-old child. Fractures of the patella are rare in children, as the patella is largely cartilaginous and has great mobility. Normally in this age closed patellar fractures cannot be diagnosed radiologically as the ossification starts only after 3 years of age. Our case is an open transverse patellar fracture in a two-year-old girl which is treated with transcartilagenous absorbable sutures, which is not found reported in the literature.
\end{abstract}

\section{Keywords}

Open Patella Fracture, Children, Transcartilagenous Sutures

\section{Introduction}

In our clinical practice, we rarely come across patella fracture in children. Being the largest sesamoid bone in the body [1], patellar fractures occur approximately at a rate of less than $1 \%$ of total paediatric fractures [2]-[4].

Patellar fractures can be caused by direct trauma, excessive contraction of the extensor mechanism, or by both. In children flexible stabilizing soft tissue structures around patella decrease the mechanical stress peaks in case of traumas. Furthermore, the thick cartilage layer is acting as a buffer in case of direct impact [4]. Open transverse fracture of patella as in our case is very rarely seen. We present that case because of being rarely seen and not found reported in the literature.

\section{Case Report}

Our case is a two years old girl who was brought to our hospital by parents with the history of accidental injury with a sickle falling directly on her right knee from about 7 
to 8 feet height, one hour before presenting to us in the casualty.

On examination there was a transverse incised wound on the anterior aspect of the right knee which measuring about $8 \mathrm{~cm}$. Patella was split transversely into almost two equal halves with a separation of about $1 \mathrm{~cm}$ [Figure 1(a) and Figure 1(b)]. So diagnosis of fracture was made in the casualty itself.

Radiograph taken did not reveal any sign of ossification. Patella was not seen on the $\mathrm{X}$-ray. Surgery was performed immediately after admission. Under general anaesthesia wound was thoroughly cleaned; after reduction of the fragments, patella was fixed by transcartilagenous simple end to end sutures with vicryl1o [Figure 2]. Skin closed with Ethilon 3-0. Postoperatively, the knee was kept in an extension cast and child was discharged on $3^{\text {rd }}$ post operative day after wound dressing. Suture removal done on $10^{\text {th }}$ post op day and pop removed after three weeks. After removal of the pop cast, physiotherapy was started which includes range of motion and quadriceps strengthening exercises. Five weeks after trauma, the patient could walk normally and it was pain free. She was able to perform a full range of motion with excellent quadriceps function by eight weeks [Figures 3(a)-(c)].

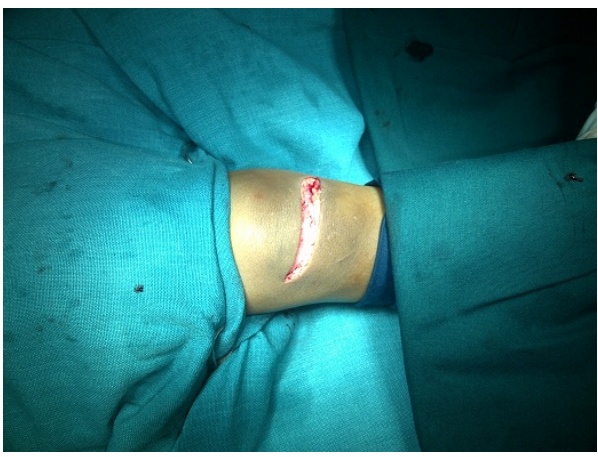

(a)

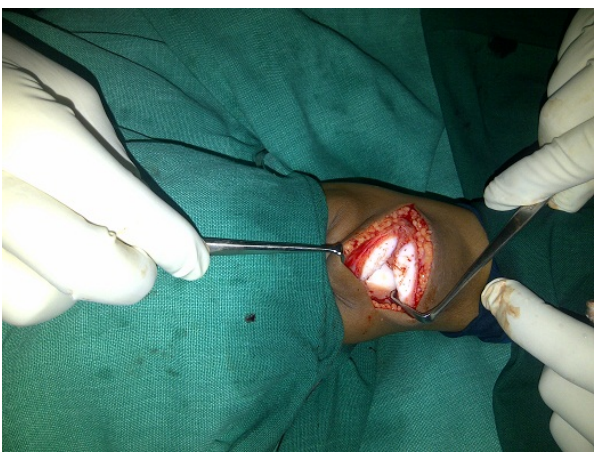

(b)

Figure 1. (a) Incised wound on the anterior aspect of the knee which measuring about $8 \mathrm{~cm}$; (b) Patella was split transversely into almost two equal halves.

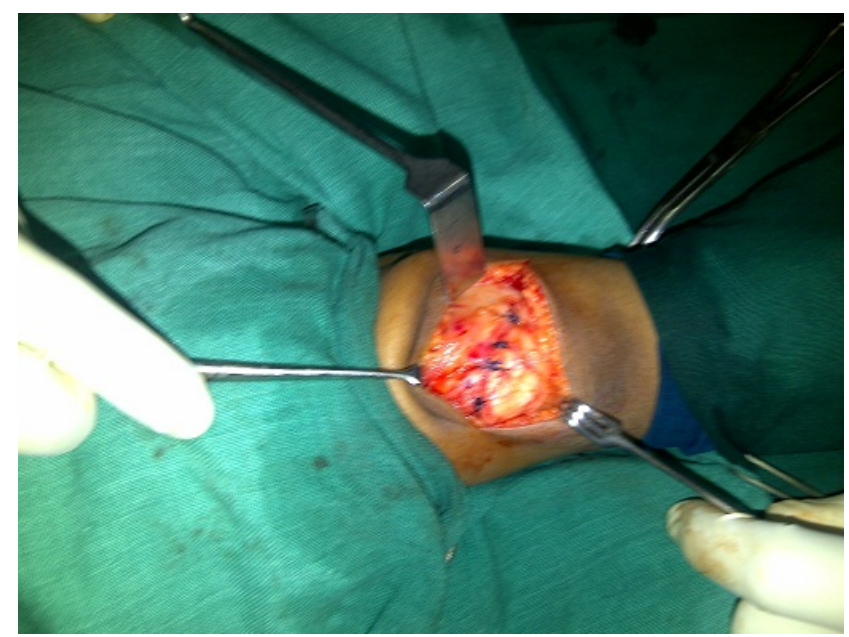

Figure 2. Patella after fixation with vicryl. 


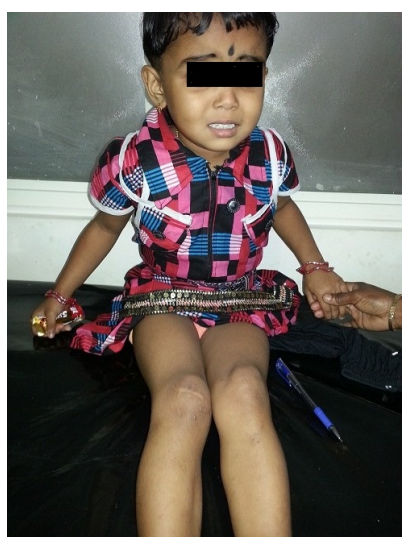

(a)

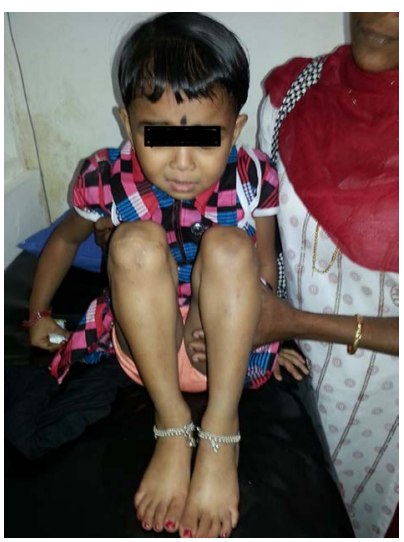

(b)

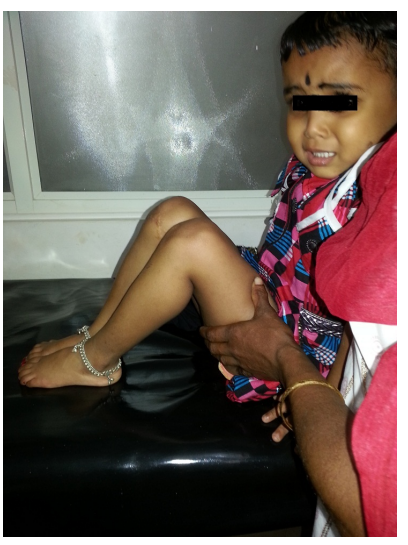

(c)

Figure 3. ROM after 6 weeks.

\section{Discussion}

Fractures of the patella are rare injuries in children because of some anatomic and biomechanical conditions [3] [4]. Ligaments, tendons, capsule, cartilage and other soft tissues are more flexible in children so joint laxity increases. Furthermore, the thick cartilage layer is acting as a buffer in case of direct impact and it also protect the patella [4] [5].

Most of patellar fractures in children are sleeve fractures and occur because of indirect traumas, Grogan et al. [6] sub classified avulsion fractures as superior (most rarely seen), inferior, medial and lateral [2] [6] [7]. Sleeve fractures [8] [9] are 57\% of all patellar fractures in children and mostly located at the distal pole. It is usually between 8 12 years of age.

Transverse fracture of the patella is rarer than avulsion fractures. It is a result of compression of patella against the distal femur because of direct blows [4]. $3 \mathrm{~mm}$ separation between the bone fragments defined as of a displaced fracture [1]. In our case, the fragments were grossly displaced.

When it comes to treatment options for patella fractures, we have options like Open reduction and the reduction held with either Tension Band Wire (TBW), modified tension band wire or a circumferential cable for comminuted fractures. Osteosynthesis with lag screws has also been described. For sleeve fractures and other avulsion fractures in which one of the fragments is too small, transosseous sutures may be used [4] [10] [11]. In our case, none of the above options were possible because of non ossified patella. So we opted for transcartilagenous sutures.

There is no such case reported in the literature.

\section{References}

[1] Beamish, A.J., Roberts, G.L. and Cnudde, P. (2012) A Case of Patellar Fractures in Monozygotic Twin Gymnasts. Sports Medicine, Arthroscopy, Rehabilitation, Therapy \& Technology, 4. http://dx.doi.org/10.1186/1758-2555-4-20

[2] Dai, L.Y. and Zhang, W.M. (1999) Knee Surg. Sports Traumatol. Arthroscv, 7, 243-245. 
http://dx.doi.org/10.1007/s001670050156

[3] Bruijn, J.D., Sanders, R.J. and Jansen, B.R. (1993) Ossification in the Patellar Tendon and Patella Alta Following Sports Injuries in Children. Complications of Sleeve Fractures after Conservative Treatment. Archives of Orthopaedic and Trauma Surgery, 112, 157-158. http://dx.doi.org/10.1007/BF00449996

[4] Schmal, H., Strohm, P.C., Niemeyer, P., Reising, K., Kuminack, K. and Sudkamp, N.P. (2010) Fractures of the Patella in Children and Adolescents. Acta Orthopaedica Belgica, 76, 644-650.

[5] Maguire, J.K. and Canale, S.T. (1993) Fractures of the Patella in Children and Adolescents. Journal of Pediatric Orthopaedics, 13, 567-571. http://dx.doi.org/10.1097/01241398-199309000-00002

[6] Grogan, D.P. and Ogden, J.A. (1992) Knee and Ankle Injuries in Children. Pediatrics in Review, 13, 429-434.

[7] Grogan, D.P., Carey, T.P., Leffers, D. and Ogden, J.A. (1990) Avulsion Fractures of the Patella. Journal of Pediatric Orthopaedics, 10, 721-730.

http://dx.doi.org/10.1097/01241398-199011000-00004

[8] Lin, S.Y., Lin, W.C. and Wang, J.W. (2011) Inferior Sleeve Fracture of the Patella. Journal of the Chinese Medical Association, 74, 98-101. http://dx.doi.org/10.1016/j.jcma.2011.01.020

[9] Labronici, P.J., Fernandes, H.J.A., Goes, R.F.A. and Reis, F.B.D. (2005) Patellar Fractures in Children (Sleeve-Typefractures). Acta Ortopédica Brasileira, 13, 253-254. http://dx.doi.org/10.1590/S1413-78522005000500009

[10] Beaty, J.H. and Kumar, A. (1994) Fractures about the Knee in Children. The Journal of Bone \& Joint Surgery, 76, 1870-1880.

[11] Veselko, M. and Kastelec, M. (2004) Inferior Patella Pole Avulsion Fractures: Osteosynthesis Compared with Pole Resection. The Journal of Bone \& Joint Surgery, 86, 696-701.

Submit or recommend next manuscript to SCIRP and we will provide best service for you:

Accepting pre-submission inquiries through Email, Facebook, LinkedIn, Twitter, etc. A wide selection of journals (inclusive of 9 subjects, more than 200 journals)

Providing 24-hour high-quality service

User-friendly online submission system

Fair and swift peer-review system

Efficient typesetting and proofreading procedure

Display of the result of downloads and visits, as well as the number of cited articles Maximum dissemination of your research work

Submit your manuscript at: http://papersubmission.scirp.org/

Or contact ojo@scirp.org 